\title{
Proximate analysis, mineral composition, phytochemical contents, antioxidant and antimicrobial activities and GC-MS investigation of various solvent extracts of cactus cladode
}

\author{
Sana BAKARI ${ }^{1}$, Amal DAOUD ${ }^{1}$, Samir FELHI ${ }^{1}$, Slim SMAOUI ${ }^{2}$, Néji GHARSALLAH ${ }^{1}$, Adel KADRI ${ }^{1,3 *}$
}

\begin{abstract}
Cladodes Powder Extracts (CPE) are known for their medicinal properties such as being an auxiliary treatment for obesity and gastrointestinal or cardiovascular disorders as well as lowering cholesterol levels. The presented results proved that CPE was found to be a rich source of carbohydrate, ash, moisture and minerals namely Magnesium, Calcium and Zinc which highlighted its good nutritional value. Moreover, the solvent extracts displayed appreciable level of polyphenols, flavonoids and tannins contents compounds which may explain their higher and varied antioxidant and antimicrobial properties. The time-kill assay revealed that the bactericidal concentration required for cladode to kill M. luteus should be less than $3.12 \mathrm{mg} / \mathrm{mL}$ (2MIC). Interestingly, GC-MS analyses of ethyl acetate CPE demonstrate the presence of six compounds. The overall data emphasize the nutritional potential of $\mathrm{CP}$ as a promising natural preservative and a substitute to the synthetic counterparts and therefore to be consumed in a healthy diet.
\end{abstract}

Keywords: cladode powder; nutritional composition; solvent extracts; GC-MS analysis; antioxidant and antimicrobial activities.

Practical Application: Cactus cladodes require a potential source of nutrients and may be used as a diet, for the development of healthy food and for the treatment of various diseases.

\section{Introduction}

Opuntia ficus-indica (L.) Mill., referred to as nopal cactus, belongs to the Cactaceae family that includes about 1500 species. It is a tropical plant characterized by its remarkable adaptation. It can grow in arid and semi-arid climates with a geographical distribution comprising Mexico, Latin America, South Africa and Mediterranean countries (Butera et al., 2002). The cladodes of this plant possess a higher potential source of nutritional fiber (Sáenz, 1997), polyphenols, vitamins and other specific compounds (Valente et al., 2010; El-Mostafa et al., 2014), and therefore are served for their nutraceutical and therapeutic effect as diarrhea, hyperlipidemia and anti-inflammatory, cosmetics and herbal remedy for diverse health problems in Tunisia (Ribeiro et al., 2010). The dehydration and grounding of the cladodes offer a large range of food products as well as pharmaceutical capsules (López et al., 2009). Due to its richness on bioactive compounds, such as phenols, flavonoids and fatty acids, cactus cladode from Opuntia species shows an interesting medicinal proprieties, including antioxidant and antimicrobial effects (Lopez-Garcia et al., 2001).

The main purpose of this investigation is to determine the proximate and mineral composition, phytochemical constituents, antioxidant and antimicrobial properties of CPE. Moreover, we characterized by gas chromatography-mass spectrometry (GC-MS), the phenolic acids components of CPE and discussed their possible health benefits.

\section{Materials and methods}

\subsection{Materials}

Gallic acid, Folin-Ciocalteu's, quercetin, $\mathrm{AlCl}_{3}$, Catechin, vanillin, Ascorbic acid, 2,2-Diphenyl-1-picrylhydrazyl (DPPH), polyoxyethylene sorbitan monolaurate (Tween-40), linoleic acid, $\beta$-Carotene, and Dimethyl sulfoxide (DMSO) were from Sigma (Sigma, France). Mueller Hinton Agar (MHA) and Potato Dextrose Agar (PDA) were from Bio-Rad (Bio-Rad, France).

\subsection{Plant material and preparation of extracts}

The cactus cladode (Opuntia ficus-indica var. inermis) was collected in July 2014 from Kasserine governorate, in west central of Tunisia. The voucher specimen (SB19) was deposited in the unity research of microbial biotechnology, Faculty of Science, University of Sfax, Tunisia. Then, the obtained material was dried to obtain a fine powder $(200 \mathrm{~g})$ which was extracted twice $(2 \times 400 \mathrm{~mL})$ using various solvents: hexane, dichloromethane, ethyl acetate, acetone and ethanol based on the method reported by Bakari et al. (2015).

\subsection{Total phenolics, flavonoids and condensed tannins contents}

Total phenolics and flavonoids contents were determined using the same protocol as reported by Bakari et al. (2015). Condensed tannins reactive to vanillin were analyzed by slight 
modification of Burns (1971) method. One milliliter (1 mL) of each extract solution was placed in a test tube and $2 \mathrm{~mL}$ of vanillin $\left(1 \%\right.$ in $\left.\mathrm{H}_{2} \mathrm{SO}_{4} 7 \mathrm{M}\right)$ in an ice bath and then incubated at $25^{\circ} \mathrm{C}$. After $15 \mathrm{~min}$, the absorbance of the solution was read at $500 \mathrm{~nm}$. Concentrations were calculated as g Catechin equivalents $(\mathrm{CE}) / \mathrm{g}$ from a calibration curve.

\subsection{Analysis by gas chromatography and mass spectrometry}

The trimethylsilyl derivatives of fatty acids were identified using GC-MS apparatus as cited by Bakari et al. (2015). A HP-5 MS capillary column was used for the GC system. Helium was used as carrier gas at a flow rate of $1 \mathrm{~mL} / \mathrm{min}$. The injection volume was $2 \mu \mathrm{L}$. Ionization energy $\mathrm{EI}$ of $70 \mathrm{eV}$ was used for mass spectroscopy detector.

The GC-MS apparatus was carried out by Chem-Station software package (Agilent Technologies). Both the injector and detector temperature were $250^{\circ} \mathrm{C}$. The oven temperature was held at $100{ }^{\circ} \mathrm{C}$ for $1 \mathrm{~min}$, increased to $260^{\circ} \mathrm{C}$ at a heating rate of $4{ }^{\circ} \mathrm{C} / \mathrm{min}$, and held for $10 \mathrm{~min}$. The identification of compounds was achieved as the same method reported by Bakari et al. (2015).

\subsection{Antioxidant activity}

$D P P H$ free radical scavenging, $\beta$-Carotene-linoleic acid bleaching assay and Ferric reducing power assay

All these tests were determined by spectrophotometric method based on the method described by Adel et al. (2011). All tests were performed in triplicate.

\section{Total antioxidant capacity (phosphomolybdenum method)}

In this assay, we used the same method of Prieto et al. (1999) with slight modification. The obtained data was expressed as $\mathrm{mg}$ of $\alpha$-tocopherol equivalents per $\mathrm{g}$ dry weight. All tests were performed in triplicate.

\subsection{Antimicrobial activity}

\section{Microorganisms and growth conditions}

Bacteria and fungi, used in this study, included Gram-positive bacteria: Bacillus subtilis JN 934392, Bacillus cereus JN 934390, Staphylococcus aureus ATCC 6538, Enterococcus faecalis, Micrococcus luteus, Listeria monocytogenes, Enterococcus and Gram-negative bacteria: Salmonella enterica sero type Enteritidis ATCC 43972, Salmonella enterica sero, Escherichia coli ATCC 25922, and Klebsiella pneumoniae. The tested fungi are Aspergillus niger, Fusarium phyllophilum AB 587006 and Penicillium sp.

Antimicrobial activity by agar diffusion method, determination of MIC, MBC and MFC by micro-dilution well method

In this part, we used the same protocol as ascribed by Daoud et al. (2015). Bacterial and fungal strains showing sensitivity to tested extracts are therefore selected to determine the minimum inhibitory and bactericidal/ fungicidal concentrations.

\subsection{Mode of antimicrobial action}

To investigate the mode of antimicrobial action, we used the same protocol as described by Daoud et al. (2015).

\subsection{Kill-time analysis}

The kill-time analysis is often applied, by following the decrease of the bacterial cells growth, over time, due to the effect of a definite extract concentration as reported by our laboratory (Daoud et al., 2015). Each test was performed twice.

\subsection{Statistical analysis}

Statistical analyses data were expressed as means \pm standard deviation of three parallel measurements. The significance of difference was calculated by EXCELL program, and values ( $\mathrm{p} \leq 0.05)$ were considered to be significant. A correlation and regression analysis was carried out using Microsoft Excel packaged in Microsoft Office 2010.

\section{Results and discussion}

\subsection{Extraction yields, proximate and mineral compositions of Cladode}

Extraction is the crucial step towards recovering and isolating phytochemicals from plant materials. As shown in Table 1, the extraction yields are between $0.83 \%$ and $7.76 \%$ and increased with the increasing polarity of the solvent: ethanol>ethyl acetate $>$ dichloromethane $>$ acetone $>$ hexane. These findings are in good agreement with the fact that extractable compounds were more pronounced with solvent polarity and confirmed the usefulness of screening process to identify the best solvent that may be used for biological activities needlessness. No literature, so far, has compared all the four solvents used in this study.

Proximate analysis is an important index to classify the nutritional value of a food material (Sousa et al., 2014). Results depicted in Table 2 show the nutrient and mineral compositions of powdered cladode. Our investigation revealed that the dominant components are carbohydrate (42.5\%), ash (19.5\%) and moisture (18.3\%); however, lipid contents were relatively lower. A sample with high level of carbohydrates can regulate nerve tissue. Ash contents give an idea about the inorganic content. They are also expected to facilitate the metabolic processes, growth and development while moisture contents display more information about the storage/shelve life and the viability of microorganisms growth. Proteins, on the other hand, can serve as enzymatic catalyst, growth control and cell differentiation. Based on protein, fat and carbohydrate contents, cladode energy content was $193.1 \mathrm{Kcal} / 100 \mathrm{~g}$ justifying its uses as a good source of nutrient.

Among the analyzed minerals, magnesium content was the highest, at about $78.7 \pm 0.0 \mathrm{mg} / 100 \mathrm{~g}$ followed, respectively, by calcium $(44.2 \pm 0.9 \mathrm{mg} / 100 \mathrm{~g})$ and zinc $(15.2 \pm 1.2 \mathrm{mg} / 100 \mathrm{~g})$; however, the other elements were found at very low amounts. The higher concentration of Magnesium in the sample provides its usefulness for the reactions involved in converting vitamin D to its active form and therefore, leading to the formation 
Table 1. Yields, total phenolic, flavonoid, condensed tannins contents and antioxidant activity of different extracts of cladode determined by DPPH free radical scavenging, FRAP, $\beta$-carotene and TAC assays. Vitamin $\mathrm{C}$ was used as standard.

\begin{tabular}{|c|c|c|c|c|c|c|c|c|}
\hline \multirow[b]{2}{*}{ Extracts } & \multirow{2}{*}{$\begin{array}{c}\text { Extracts } \\
\text { Yields (\%) }\end{array}$} & \multirow{2}{*}{$\begin{array}{c}\text { TPC } \\
\text { (mg GAE/g) }\end{array}$} & \multirow{2}{*}{$\begin{array}{c}\text { TFC } \\
(\mathrm{mg} \mathrm{QE} / \mathrm{g})\end{array}$} & \multirow{2}{*}{$\begin{array}{c}\text { CTC } \\
(\mathrm{mg} \mathrm{CatE} / \mathrm{g})\end{array}$} & \multicolumn{2}{|c|}{$\mathrm{IC}_{50}(\mu \mathrm{g} / \mathrm{mL})$} & \multirow{2}{*}{$\begin{array}{c}\mathrm{EC}_{50}(\mu \mathrm{g} / \mathrm{mL}) \\
\text { FRAP }\end{array}$} & \multirow{2}{*}{$\begin{array}{c}\text { CAT (mg of } \\
\text { a-tocopherol } \\
\text { /g extract) }\end{array}$} \\
\hline & & & & & DPPH activity & $\beta$-carotene & & \\
\hline Hexane & $0.8 \pm 0.0$ & $165.1 \pm 0.5$ & $16.2 \pm 0.0$ & $27.5 \pm 0.1$ & $280 \pm 0.9$ & $150 \pm 0.1$ & $820 \pm 0.4$ & $61.5 \pm 1.3$ \\
\hline Dichloromethane & $1.0 \pm 0.2$ & $256.7 \pm 1.4$ & $28.1 \pm 0.0$ & $13.5 \pm 0.0$ & $150 \pm 1.4$ & $317 \pm 1.4$ & $825 \pm 0.1$ & $113.8 \pm 1.7$ \\
\hline Ethyl acetate & $1.0 \pm 0.0$ & $103.0 \pm 0.0$ & $69.1 \pm 1.3$ & $7.4 \pm 0.0$ & $180 \pm 1.4$ & $315 \pm 0.1$ & $125 \pm 0.4$ & $72.3 \pm 1.0$ \\
\hline Acetone & $0.8 \pm 0.0$ & $594.2 \pm 0.0$ & $221.7 \pm 0.6$ & $8.6 \pm 0.0$ & $130 \pm 1.4$ & $135 \pm 0.0$ & $325 \pm 0.1$ & $62.5 \pm 1.2$ \\
\hline Ethanol & $7.7 \pm 0.2$ & $264.6 \pm 0.5$ & $109.1 \pm 0.2$ & $29.5 \pm 0.0$ & $140 \pm 0.1$ & $200 \pm 0.1$ & $620 \pm 0.2$ & $160.8 \pm 1.9$ \\
\hline Vitamin C & - & - & - & - & $114 \pm 0.7$ & $190 \pm 1.0$ & $330 \pm 0.6$ & - \\
\hline
\end{tabular}

Each value represents the mean \pm S.D. $(\mathrm{n}=3) ;(\mathrm{mg} \mathrm{GAE} / \mathrm{g})$ : $\mathrm{mg}$ of gallic acid equivalent per $\mathrm{g}$ of dry plant extract; $(\mathrm{mg} \mathrm{QE} / \mathrm{g})$ : $\mathrm{mg}$ of quercetin equivalent per g of dry plant extract; $(\mathrm{mg} \mathrm{CatE} / \mathrm{g}): \mathrm{mg}$ of Catechin equivalent per $\mathrm{g}$ of dry plant extract; $\mathrm{IC}_{50}(\mu \mathrm{g} / \mathrm{mL})$ : values corresponding to the amount of extract required to scavenge $50 \%$ of radicals present in the reaction mixture; $\mathrm{EC}_{50}(\mu \mathrm{g} / \mathrm{mL})$ : effective concentration corresponding to the value of absorbance (0.5); ( $\mathrm{mg} \alpha$-tocopherol $/ \mathrm{g}$ extract): $\mathrm{mg}$ of $\alpha$-tocopherol equivalent per $\mathrm{g}$ of dry plant extract; (-): not tested.

Table 2. Proximate and mineral composition of cladodes powder.

\begin{tabular}{lc}
\hline \multicolumn{3}{c}{ Proximate analysis } \\
\hline Moisture & $18.3 \%$ \\
Ash & $19.5 \%$ \\
Crude lipid & $0.8 \%$ \\
Crude protein & $3.8 \%$ \\
Carbohydrate & $42.5 \%$ \\
Energy (kcal/100 g) & $193.0 \%$ \\
\hline \multicolumn{2}{c}{ Minerals composition $(\mathrm{mg} / 100 \mathrm{~g})$} \\
\hline Magnesium $(\mathrm{Mg})$ & $78.7 \pm 0.8$ \\
Iron $(\mathrm{Fe})$ & $1.0 \pm 0.1$ \\
Zinc $(\mathrm{Zn})$ & $15.2 \pm 1.2$ \\
Cadmium $(\mathrm{Cd})$ & - \\
Copper $(\mathrm{Cu})$ & $0.5 \pm 0.1$ \\
Plumb (Pb) & $0.1 \pm 0.1$ \\
Nickel $(\mathrm{Ni})$ & $1.0 \pm 0.1$ \\
Mercury $(\mathrm{Hg})$ & - \\
Calcium $(\mathrm{Ca})$ & $44.2 \pm 0.9$ \\
\hline
\end{tabular}

$(-)$ : not determined.

of Adenosine triphosphate (ATP), as constituent, to release parathyroid hormone and to relax the muscles (Elinge et al., 2012). The second important element found in cladode, Calcium, is known to help ease insomnia, regulate the passage of nutrients through cell walls and stimulate muscle (Dawson-Hughes et al., 1997). The considerable concentration of Zinc gives significant value to the cladode, because this element could be required by the body to maintain the proper functioning of the smell sense, to keep the immune system healthy, to build proteins, to trigger enzymes and also to create DNA. The obtained results were very close to those found by El-Mostafa et al. (2014), i.e. the richness of cladode in magnesium and calcium (78.8 and $16.2 \mathrm{mg} / 100 \mathrm{~g}$ ). Among the Cladode minerals, the contents of cadmium and mercury were very low, no more than $0.02 \mathrm{mg} / 100 \mathrm{~g}$; this confirms that cladode is a good source of beneficial minerals (Habib et al., 2016; Zou et al., 2015).

\subsection{Phytochemical characterization}

Polyphenols have been reported to provide many beneficial health effects because of their radical scavenging ability due to their hydroxyl groups. The results of TPC of CE are reported in
Table 1. Among the five extracts, the highest amount was allowed to acetone $(594.2 \pm 0.0 \mathrm{mg} \mathrm{GAE} / \mathrm{g}$ ) followed respectively by ethanol (264.6 \pm 0.5$)$ and dichloromethane ( $256.7 \pm 1.4 \mathrm{mg} \mathrm{GAE} / \mathrm{g})$, hexane $(165.1 \pm 0.5 \mathrm{mg} \mathrm{GAE} / \mathrm{g})$ and ethyl acetate $(103.0 \pm 0.0 \mathrm{mg} \mathrm{GAE} / \mathrm{g})$ extracts. Data obtained from TPC depend directly on the solvents polarity and the solubility of each compound in the solvent used for the extraction process. Despite the presented data, ethanol and acetone have approximately the same polarity index (PI $=5.2$ and 5.4, respectively) but they displayed significantly different levels of polyphenol content. The current study also demonstrated that the lowest polar solvent (acetone) possesses the highest TPC but the higher polar solvent (ethanol) exhibited the weaker TPC, this revealed that higher amount of low polar phenolic compounds existed in CE.

Flavonoids are widespread plant secondary metabolites including flavones, flavonols and condensed tannins that modulate lipid peroxidation (Shi et al., 2006). They occur as glycosides and contain several phenolic hydroxyl groups on their ring structure. Regarding the different extracts (Table 1), the amount of TFC ranged from $16.2 \pm 0.0 \mathrm{mg} \mathrm{QE} / \mathrm{g}$ to $221.7 \pm 0.6 \mathrm{mg} \mathrm{QE} / \mathrm{g}$, with the highest level observed in acetone extract, and was 2-fold higher than ethanol extract, whereas the lowest level was obtained in the hexane extract (13 times lower than acetone extracts). This suggests that acetone proved to be an efficient solvent for better flavonoids extraction.

Tannins are important water soluble plant secondary metabolites obtained by the condensation of simple phenolics leading to condensed tannins which are divided into hydrolysable and condensed proantho-cyanidins. They also have powerful biological activities and nutritional effects.

The results depicted in Table 1 showed high concentrations of CTC found in ethanol $(29.5 \pm 0.0 \mathrm{mg}$ CatE/g) followed respectively by hexane, dichloromethane, acetone and ethyl acetate. In the present investigation the ability of solvents to extract CTC from Cladode may arise from the structural chemistry and/or quantity of condensed tannin found in five various extracts. Acetone is a polar aprotic solvent that cannot provide $\mathrm{OH}$-ions. However, ethanol is a polar protic solvent that can provide $\mathrm{OH}$-ions, and therefore facilitate its interaction with polar functional groups on the tannins. This may explain the lowest effect of acetone to extract tannins as compared to ethanol. 
As shown, acetone is an efficient solvent to extract TPC and TFC, whereas CTC were more extracted by ethanol as compared to other extracts. We explained this by the fact that phenolic compounds are more soluble in polar organic solvents than in non-polar organic solvents. Overall, phenolic compounds often associated with other biomolecules and solvents were suitable for the extraction and possess the ideal chemical properties for antioxidant because of their ability to react with reactive oxygen species and, therefore, they act both as hydrogen and electron donors (Ghasemzadeh et al., 2011). Statistically Significant difference values were found between TPC, TFC and CTC $(\mathrm{p}<0.05)$.

\subsection{GC-MS analysis of ethyl acetate extract}

The results of GC-MS analysis of ethyl acetate CE are tabulated in Table 3 and allowed to the elucidation of 12 compounds which represent about $80.5 \%$ of the relative area with the main constituent being ferulic acid (34.8\%), followed by palmitic acid (20.9\%), oleic acid (11.0\%), linoleic acid (7.0\%), caffeic acid $(2.6 \%)$ and vanillic acid occurring in small quantities $(0.1 \%)$. These compounds were known for their beneficial health effects such as unsaturated fatty acids (oleic and linoleic acid) which can prevent cardiovascular diseases (Ranalli \& Angerosa, 1996), vanillic acid and $p$-coumeric acid are used as antimicrobial agent (Lou et al., 2012; Teke et al., 2011). Ferulic acid can inhibit the photo-peroxidation of linoleic acid at high concentrations (Wang, 2003) and caffeic acid was found to possess higher antioxidant activity (Kim \& Lee, 2004).

\subsection{Antioxidant activity}

Due to the complexity of the oxidation- antioxidation processes and to the different nature and function of antioxidant components found in extracts, it is evident that one test is incapable to provide a clear data of the antioxidant capacity of some samples (Khaled-Khodja et al., 2014). On the other hand, the solubility of antioxidant compounds as a function of solvent has gained much importance since they possess a significant role in the recovery of compounds at the extraction time. Therefore,

Table 3. Chemical composition of ethyl acetate extract from cladode powder detected by GC-MS.

\begin{tabular}{clcc}
\hline No. & \multicolumn{1}{c}{ Compounds } & $\mathrm{t}_{\mathrm{R}}(\min )$ & Peak area $(\%)$ \\
\hline 1 & Benzoic acid & 6.9 & 0.5 \\
2 & p-hydroxyphenylacetic acid & 18.1 & 0.2 \\
3 & Vanillic acid & 19.8 & 0.1 \\
4 & Tetradecanoic acid & 21.8 & 0.9 \\
5 & p-Coumaric acid & 25.2 & 0.9 \\
6 & Palmitic acid & 26.5 & 20.9 \\
7 & Ferulic acid & 27.6 & 34.8 \\
8 & Heptadecanoic acid & 27.9 & 0.7 \\
9 & Caffeic acid & 29.0 & 2.6 \\
10 & Linoleic acid & 31.5 & 7.0 \\
11 & Oleic acid & 31.6 & 11.0 \\
12 & Octadecanoic acid & 32.2 & 0.3 \\
\hline
\end{tabular}

Compounds listed in order of retention time; $\mathrm{t}_{\mathrm{R}}=$ retention time (min). in this study, four methods have been applied to evaluate the antioxidant capacity of CE in different solvents.

DPPH assay is a method used to test the ability of compounds acting as free radical scavengers or hydrogen donors. Findings on DPPH assay indicated a positive linear correlation and significant variation with CTC and TFC $(\mathrm{p}<0.05)$. The results expressed in terms of $\mathrm{IC}_{50}$ (concentration of the antioxidant needed to scavenge $50 \%$ of DPPH) were compared with the standard ascorbic acid and showed that DPPH radical-scavenging effect was dose-dependent (Table 1). All extracts demonstrate DPPH radical-scavenging capacity in a concentration-dependent manner, but less than standard. The values ranged from $130 \pm 1.4$ to $280 \pm 0.9 \mu \mathrm{g} / \mathrm{mL}$ with the highest level ascribed to acetone and ethanol $\left(\mathrm{IC}_{50}=130 \pm 1.4\right.$ and $140 \pm 0.1 \mu \mathrm{g} / \mathrm{mL}$, respectively) and they were close to the standard $\left(\mathrm{IC}_{50}=114 \pm 0.7 \mu \mathrm{g} / \mathrm{mL}\right)$, however, the other extracts were less effective. As shown, acetone extracts with high amounts of TPC is a good DPPH radical scavenger. This may be explained by its richness in substances possessing hydrogen-donating capabilities via their hydroxyl groups as well as their ability to donate electrons to act as an antioxidant, and therefore may be used as a potential source of natural antioxidants. Several reports have finally shown a relationship between total phenolic contents and antioxidant power of plants extracts (Bakari et al., 2015; Augusto et al., 2014).

The FRAP assay is used to study the capability of extracts to reduce the ferricyanide $\left(\mathrm{Fe}^{3+}\right)$ complex to their ferrous form $\left(\mathrm{Fe}^{2+}\right)$ by donating an electron. As shown in Table 1, the strongest antioxidant activity via this assay was recorded to ethyl acetate extract $\left(\mathrm{EC}_{50}=125 \pm 0.4 \mu \mathrm{g} / \mathrm{mL}\right)$ followed by those of acetone $\left(\mathrm{EC}_{50}=325 \pm 0.1 \mu \mathrm{g} / \mathrm{mL}\right)$, ethanol $\left(\mathrm{EC}_{50}=620 \pm 0.2 \mu \mathrm{g} / \mathrm{mL}\right)$, hexane $\left(\mathrm{EC}_{50}=820 \pm 0.4 \mu \mathrm{g} / \mathrm{mL}\right)$ and dichloromethane extract $\left(\mathrm{EC}_{50}=825 \pm 0.1 \mu \mathrm{g} / \mathrm{mL}\right)$. The differences in scavenging capacities between the samples may be related to the present bioactive compounds which can determine their electron-donating abilities. There are apparent linear relationships between antioxidant capacity, tested with FRAP assay, and TPC with a high significant level $(\mathrm{p}<0.05)$.

The $\beta$-carotene bleaching test was used to determine the ability of $\mathrm{CE}$ to inhibit the oxidation of $\beta$-carotene. The linoleic acid peroxidation effect of various extracts and standards were dose-responsive. Variations between TPC, TFC and CTC and $\beta$-carotene assays were positively high and significant $(\mathrm{p}<0.05)$. The antioxidant capacity of $\mathrm{CE}$ as determined by $\mathrm{IC}_{50}$ was found to decrease in the order of ascorbic acid, acetone, hexane, ethanol, ethyl acetate and dichloromethane (Table 1). In this test, we could conclude that results were consistent with those obtained from the DPPH assay with the marked antioxidant activity recorded to acetone extract $\left(\mathrm{IC}_{50}=135.0 \pm 0.0 \mu \mathrm{g} / \mathrm{mL}\right)$ which was 0.7 -fold lower than the positive control.

For the phosphomolybdenum assay which is a quantitative method based on the reduction of $\mathrm{Mo}^{6+}$ to $\mathrm{Mo}^{5+}$ by the formation of a green phosphate/Mo (V) complex at acidic $\mathrm{pH}$. The obtained results in Table 1, demonstrate a dose dependent manner variation with the highest activity ascribed to ethanol $(160.8 \pm 1.1 \mathrm{mg}$ a-tocopherol/g of extract) followed by dichloromethane $(113.8 \pm 1.7 \mathrm{mg}$ of $\alpha$-tocopherol/g of extract), ethyl acetate $(72.3 \pm 1.03 \mathrm{mg}$ of 
$\alpha$-tocopherol $/ \mathrm{g}$ extract), acetone $(62.5 \pm 1.2 \mathrm{mg}$ of $\alpha$-tocopherol $/ \mathrm{g}$ of extract) and hexane extracts (61.5 $\pm 1.3 \mathrm{mg} \alpha$-tocopherol/g of extract). The increase in antioxidant activity as increasing in solvent polarity may be related to their potential for extracting molecules with higher antioxidant power. Significant differences were observed among CTC and TAC assay $(\mathrm{p}<0.05)$ but not for TPC and TFC $(\mathrm{p}>0.05)$.

\subsection{Correlation between TPC, TFC, CTC and antioxidant assays}

In general, antioxidant activity is correlated with phenolic content and with the presence of other constituents such as flavonoids, glycosides, alkaloids, carotenoids, vitamins, and other secondary metabolites which are also known as good contributors.

The results summarized in Table 4 indicated a positive, significant and linear correlation was obtained between total antioxidant activity, TPC and TFC for all extracts. Correlation coefficient $\left(\mathrm{R}^{2}\right)$ of all extracts demonstrate a moderate correlation between different antioxidant tests, TPC content with $\mathrm{R}^{2}$ values 0.560 for DPPH and $\beta$-carotene. On the other hand, the corresponding value for flavonoids is $0.631,0.551,0.421$ for DPPH, FRAP and $\beta$-carotene, respectively with significant differences $(\mathrm{p}<0.05)$.

Table 4. Correlation between TPC, TFC and CTC with FRAP, DPPH, $\beta$-carotene and TAC assays.

\begin{tabular}{cllcc}
\hline & \multicolumn{4}{c}{ Correlation $\left(\mathrm{R}^{2}\right)$} \\
\cline { 2 - 5 } & DPPH & FRAP & $\beta$-carotene & TAC \\
\hline TPC & $0.560^{* *}$ & $0.144^{*}$ & $0.560^{*}$ & $0.116^{* *}$ \\
TFC & $0.631^{*}$ & $0.551^{* *}$ & $0.421^{*}$ & $0.087^{* *}$ \\
CTC & $0.421^{*}$ & $0.671^{* *}$ & $0.413^{*}$ & $0.497^{*}$ \\
\hline
\end{tabular}

${ }^{*}=\mathrm{p}<0.05$ : statistically significant difference; ${ }^{* *}=\mathrm{p}>0.05$ : no statistically significant difference.
CTC content and FRAP assay illustrate a higher correlation (0.671). The fact that there is a rather poor correlation between TPC, TFC and CTC content in the cladode extracts and the TAC assay was referred to the presence of other components, in CE. It is also possible that the radicals used in the TAC assay may not be effective in detecting the antioxidant activity of antioxidants and this new assay need to be developed.

\subsection{Antimicrobial activity}

The in vitro antimicrobial potentialities of $\mathrm{CE}$ was screened against 13 microorganisms, including 10 bacteria and 3 fungi and was evaluated by the presence or absence of the diameters of inhibition zones (DIZ), minimum inhibitory concentrations (MIC), minimum bactericidal concentrations (MBC) and minimum fungicidal concentrations (MFC). As shown in Table 5 and 6 , all extracts exhibited various antimicrobial powers against all the tested microorganisms with the higher inhibitory activity allowed to Gram-positive bacteria. We remark that the highest DIZ was obtained with ethyl acetate extract $(28.0 \pm 1.0 \mathrm{~mm}$ and $20.0 \pm 1.0 \mathrm{~mm}$ ) against $M$. luteus and $L$. monocytogenes, respectively, followed by dichloromethane $(22.0 \pm 0.0 \mathrm{~mm})$ against $S$. aureus band also was with moderate, weaker or no activity against the other strains. Gram-positive bacteria M. luteus demonstrated more sensitivity to the ethyl acetate extract than Gram-negative bacteria and fungi. Among Gram negative bacteria, acetone extract exerted the highest activity $(16.0 \pm 0.0$ and $16.5 \pm 0.5 \mathrm{~mm})$ against $S$. Enteritidis and S. Typhimurium, respectively, as compared to the positive control. E. coli and K. pneumoniae were resistant to all extracts except to ethyl acetate and they present moderate activity. As expected, our results generally revealed that only ethyl acetate exhibited moderate antifungal activity as compared with standard drugs, with mean inhibition zone ranging from $10.0 \pm 0.1$ to $11.5 \pm 0.5 \mathrm{~mm}$, however, no resistance was observed with ethanol and acetone extracts against all strains.

Table 5. Effect of cactus cladode extract on the growth of pathogenic microorganisms $(n=3)$.

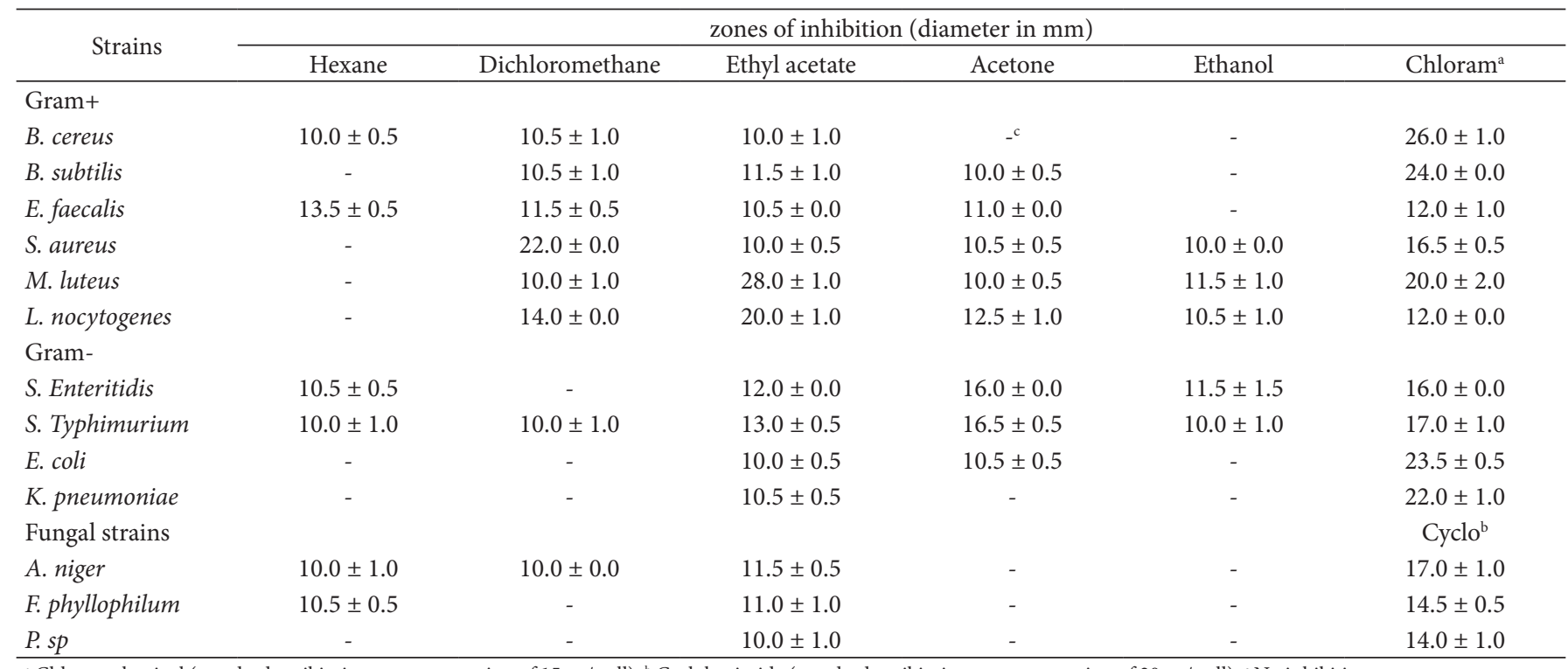

${ }^{\mathrm{a}}$ Chloramphenicol (standard antibiotic at a concentration of $\left.15 \mu \mathrm{g} / \mathrm{well}\right) ;{ }^{\mathrm{b}}$ Cycloheximide (standard antibiotic at a concentration of $20 \mu \mathrm{g} /$ well); ${ }^{\mathrm{c}}$ No inhibition. 
Bakari et al.

Table 6. Determination of MIC (mg/mL), MBC (mg/mL), MFC (mg/mL), MBC/MIC and MFC/MIC of cladode powder extracts.

\begin{tabular}{|c|c|c|c|c|c|c|c|c|c|c|c|c|c|c|c|}
\hline Extracts & & Hexane & & Dic & orome & & & nyl acet & & & Acetone & & & Ethano & \\
\hline Strains & MIC & $\mathrm{MBC}$ & $\mathrm{a}$ & $\mathrm{MIC}$ & $\mathrm{MBC}$ & $\mathrm{a}$ & MIC & $\mathrm{MBC}$ & $\mathrm{a}$ & $\mathrm{MIC}$ & $\mathrm{MBC}$ & $\mathrm{a}$ & MIC & $\mathrm{MBC}$ & $\mathrm{a}$ \\
\hline B. cereus & 3.12 & 12.5 & 4 & 6.25 & 12.5 & 2 & 3.12 & 12.5 & 4 & - & - & - & - & - & - \\
\hline B. subtilis & - & - & - & 1.56 & 6.25 & 4 & 1.56 & 12.5 & 8 & 3.12 & 12.5 & 4 & - & - & - \\
\hline E. faecalis & 3.12 & 12.5 & 4 & 3.12 & 12.5 & 4 & 1.56 & 12.5 & 8 & 3.12 & 12.5 & 4 & - & - & - \\
\hline S. aureus & - & - & - & 6.25 & 25 & 4 & 3.12 & 12.5 & 4 & 3.12 & 12.5 & 4 & 6.25 & 25 & 4 \\
\hline M. luteus & 1.56 & 6.25 & 4 & 1.56 & 12.5 & 8 & 1.56 & 3.12 & 2 & 1.56 & 6.25 & 4 & 3.12 & 12.5 & 4 \\
\hline L. monocytogenes & 3.12 & 6.25 & 2 & 6.25 & 25 & 4 & 1.56 & 6.25 & 4 & 1.56 & 12.5 & 8 & 1.56 & 6.25 & 4 \\
\hline S. Enteritidis & 1.56 & 12.5 & 8 & - & - & - & 3.12 & 12.5 & 4 & 6.25 & 25 & 4 & 3.12 & 12.5 & 4 \\
\hline S. Typhimurium & 3.12 & 12.5 & 4 & 3.12 & 12.5 & 4 & 1.56 & 12.5 & 8 & 6.25 & 25 & 4 & 3.12 & 12.5 & 4 \\
\hline E. coli & - & - & - & - & - & - & 1.56 & 6.25 & 4 & 6.25 & 25 & 4 & - & - & - \\
\hline K. pneumoniae & - & - & - & - & - & - & 12.5 & 25 & 2 & - & - & - & - & - & - \\
\hline Fungal strains & MIC & MFC & $\mathrm{b}$ & MIC & MFC & $\mathrm{b}$ & MIC & MFC & $\mathrm{b}$ & MIC & MFC & $\mathrm{b}$ & MIC & MFC & $\mathrm{b}$ \\
\hline A. niger & 3.12 & 12.5 & 4 & 1.56 & 12.5 & 8 & - & - & - & 25 & $>50$ & 2 & - & - & - \\
\hline F. phyllophilum & 12.5 & 25 & 2 & - & - & - & - & - & - & 6.25 & 12.5 & 2 & - & - & - \\
\hline P. $s p$ & - & - & - & - & - & - & - & - & - & 6.25 & 25 & 4 & - & - & - \\
\hline
\end{tabular}

$\mathrm{MIC}=$ Minimum inhibitory concentrations; $\mathrm{MBC}=$ Minimum bactericidal concentrations; $\mathrm{MFC}=$ Minimum fungicidal concentrations; $\mathrm{a}=\mathrm{MBC} / \mathrm{MIC} ; \mathrm{b}=\mathrm{MFC} / \mathrm{MIC}$.

The higher resistance of Gram-negative bacteria as compared to Gram-positive bacteria is ascribed to the differences in the cell membrane of these bacterial groups. In fact, Gram-negative bacteria is essentially constituted of a lipopolysaccaharide that blocks the penetration of hydrophobic oil and therefore avoids the accumulation of organic extracts in target cell membrane; whereas in Gram-positive, the lipophilic ends of the lipoteichoic acids of the cell membrane may facilitate penetration by hydrophobic compounds (Pompeu et al., 2015). It has been reported that the antimicrobial activity of flavonoids may be due to their ability to complex with extracellular, protein and bacterial cell wall while that of tannins was explained by their ability to inactivate microbial adhesions, enzymes and cell envelop (Cowan, 1999).

\subsection{Mode of antimicrobial action}

The mechanism of antibiosis of the extracts was determined using $\mathrm{MIC}_{\text {index }}$ as given by Shanmughapriya et al. (2008) with determining the ratio of $\mathrm{MBC} / \mathrm{MIC}$ for bacteria and when the $\mathrm{MBC} / \mathrm{MIC}$ or $\mathrm{MFC} / \mathrm{MIC}$ ratio $\leq 2.0$, the extract was considered as bactericidal or fungicidal or otherwise bacteriostatic or fungistatic. If the ratio is $\geq 16.0$, the extract was considered ineffective (CLSI, 2009). According to the results listed in Table 6, it can be concluded that ethyl acetate extract exerted a bactericidal effect against $M$. luteus and $K$. pneumonia with the same trends observed against $B$. cereus for dichloromethane extract while the other extracts possess bacteriostatic or ineffective effect against all strains. Among fungi strains, only acetone extract exerted bactericidal effect against $A$. niger and F. phyllophilum and hexane extract against F. phyllophilum, however, the other ones were ineffective except for $A$. niger in hexane and dichloromethane and $P . s p$ in acetone extracts.

\subsection{Kill-time analysis}

In this assay, depending on the effect of the Cladode ethyl acetate extract on the viable counts of selected bacteria such as $M$. luteus was investigated to further confirm its effect and clarify its mechanism of action. Compared to the control, the results presented in Figure 1 indicated that the $M$. luteus strain

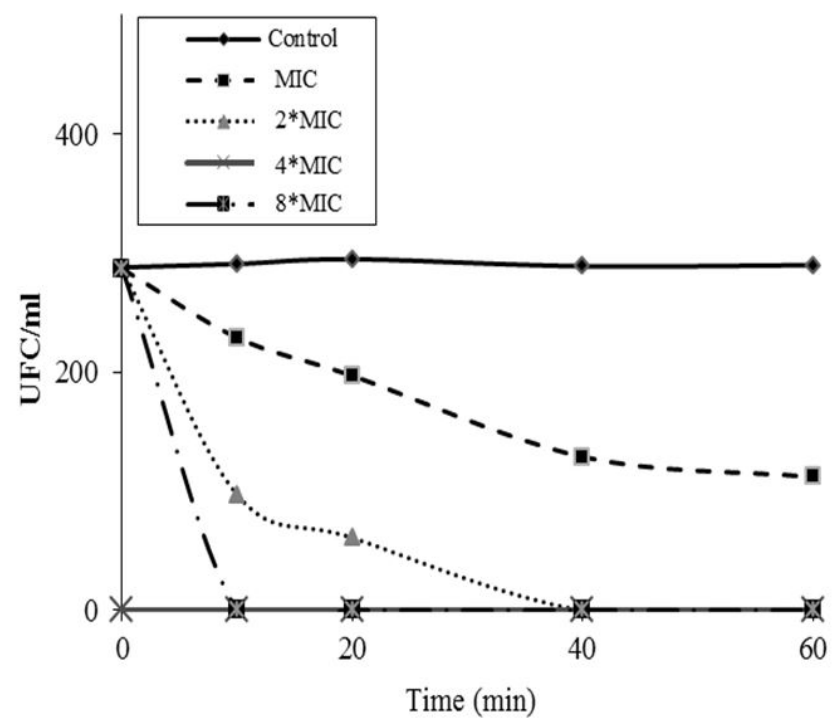

Figure 1. Bactericidal effect of cladode ethyl acetate extract on Micrococcus luteus strain. Samples were incubated at different time and viability was determined by the plate count procedure (CFU: colony forming unit).

treated with the cladode ethyl acetate extract at the MIC values $(1.56 \mathrm{mg} / \mathrm{mL})$ showed a decrease in the number of viable cells over the $60 \mathrm{~min}$ period of the test reaching $112.0 \mathrm{CFU} / \mathrm{mL}$. Using higher concentrations of $2 \mathrm{MIC}, 4 \mathrm{MIC}$ and $8 \mathrm{MIC}$ $(3.12,6.25$ and $12.50 \mathrm{mg} / \mathrm{mL})$ no viable cells were observed after $10 \mathrm{~min}$. As a consequence, the bactericidal concentration required for cladode to kill $M$. luteus should be less than $3.12 \mathrm{mg} / \mathrm{mL}$ (2MIC). These results showed that the treatment time and concentration of Cladode extracts had great influences on antibacterial activity.

\section{Conclusions}

In this study, our results highlight the higher nutritional value of $\mathrm{CE}$ as a source of carbohydrate, ash and moisture and the mineral analysis indicated that $\mathrm{Mg}, \mathrm{Ca}$ and $\mathrm{Zn}$ found to be 
abundant with other micro elements. Phytochemical constituents revealed the capacity of $\mathrm{CP}$ as a good source of polyhenolic compounds such as TPC, TFC and CTC and were correlated with different antioxidant assays. Also, the solvent extracts, especially ethyl acetate and acetone, displayed promising and varied degree of antimicrobial activity against a panel of human and food-borne pathogenic strains. As a consequence, antibacterial activity was related to the richness of this extract in phenolic compounds. The mechanism of antibiosis of the extracts exhibited bacteriostatic or fungi static effect rather than bactericidal activities. However, the Time kill kinetics of ethyl acetate extract revealed that the bactericidal concentration required for cladode to kill $M$. luteus should be less than 2MIC. This finding allows confirming the use of $\mathrm{CP}$ and $\mathrm{CPE}$ as a potential source for folk medicine, food preservation, the exploration of new compounds as antimicrobial and antioxidant agents and possibly as new tools for preventing various human diseases. Furthermore, it is hereby recommended that research should be done towards isolation, purification of active antioxidant and antibacterial ingredients in CP for food and pharmaceutical industry to promote their consumption.

\section{References}

Adel, K., Zied, Z., Ines, B. C., Neacute ji, G., Mohamed, D., \& Ahmed, B.. (2011). Chemical composition and in vitro antioxidant activities of Thymelaea hirsuta L. essential oil from Tunisia. African Journal of Biotechnology, 10(15), 2930-2935. http://dx.doi.org/10.5897/ AJB11.028.

Augusto, T. R., Salinas, E. S. S., Alencar, S. M., D’arce, M. A. B. R., Camargo, A. C., \& Vieira, T. M. F. S. (2014). Phenolic compounds and antioxidant activity of hydroalcoholic extracts of wild and cultivated murtilla (Ugnimolinae Turcz.). Food Science and Technology, 34(4), 667-673. http://dx.doi.org/10.1590/1678-457X.6393.

Bakari, S., Ncir, M., Felhi, S., Hajlaoui, H., Saoudi, M., Gharsallah, N., \& Kadri, A. (2015). Chemical composition and in vitro evaluation of total phenolic, flavonoid, and antioxydant properties of essential oil and solvent extract from the aerial parts of Teucrium polium grown in Tunisia. Food Science and Biotechnology, 24(6), 1943-1949.

Burns, R. E. (1971). Method for estimation of tannin in grain sorghum. Agronomy Journal, 63(3), 511-512. http://dx.doi.org/10.2134/agron j1971.00021962006300030050x.

Butera, D., Tesoriere, L., di Gaudio, F., Bongiorno, A., Allegra, M., Pintaudi, A. M., Kohen, R., \& Livrea, M. A. (2002). Antioxidant activities of sicilian prickly pear (Opuntiaficusindica) fruit extracts and reducing properties of its betalains: Betanin and indicaxanthin. Journal of Agricultural and Food Chemistry, 50(23), 6895-6901. PMid:12405794. http://dx.doi.org/10.1021/jf025696p.

Clinical and Laboratory Standard Institute - CLSI. (2009). Methods for dilution antimicrobial susceptibility tests for bacteria that grow aerobically: approved standard (CLSI Document, Vol. M07-A8). 8th ed. Wayne: CLSI.

Cowan, M. M. (1999). Plants products as antimicrobial agents. Clinical Microbiology Reviews, 12(4), 564-582. PMid:10515903.

Daoud, A., Malika, D., Bakari, S., Hfaiedh, N., Mnafgui, K., Kadri, A., \& Gharsallah, N.. (2015). Assessment of polyphenol composition, antioxidant and antimicrobial properties of various extracts of Date Palm Pollen (DPP) from two Tunisian cultivars. Arabian Journal of Chemistry. In press. http://dx.doi.org/10.1016/j.arabjc.2015.07.014.

Dawson-Hughes, B., Harris, S. S., Krall, E. A., \& Dallal, G. E. (1997). Effect of calcium and vitamin D supplementation on bone density in men and women 65 years of age or older. The New England Journal of Medicine, 337(10), 670-676. PMid:9278463. http://dx.doi. org/10.1056/NEJM199709043371003.

Elinge, C. M., Muhammad, A., Atiku, F. A., Itodo, A. U., Peni, I. J., Sanni, O. M., \& Mbongo, A. N. (2012). Proximate, mineral and antinutrient composition of pumpkin (Cucurbitapepo L) seeds extract. International Journal of Plant Research, 2(5), 146-150. http://dx.doi. org/10.5923/j.plant.20120205.02.

El-Mostafa, K., Kharrassi, Y., Badreddine, A., Andreoletti, P., Vamecq, J., Kebbaj, M. H., Latruffe, N., Lizard, G., Nasser, B., \& CherkaouiMalki, M. (2014). Nopal cactus (Opuntiaficus-indica) as a source of bioactive compounds for nutrition, health and disease. Molecules, 19(9), 14879-1490. PMid:25232708. http://dx.doi.org/10.3390/ molecules190914879.

Ghasemzadeh, A., Jaafar, H., \& Rahmat, A. (2011). Effects of solvent type on phenolics and flavonoids content and antioxidant activities in two varieties of young ginger (Zingiber officinale Roscoe) extracts. Journal of Medicinal Plants Research, 5(7), 1147-1154. Retrieved fromhttp://www.academicjournals.org/JMPR

Habib, G., Khan, N. A., Sultan, A., \& Ali, M. (2016). Nutritive value of common tree leaves for live stock in the semi-arid and arid range lands of Northern Pakistan. Livestock Science, 184, 64-70. http:// dx.doi.org/10.1016/j.livsci.2015.12.009.

Khaled-Khodja, N., Boulekbache-Makhlouf, L., \& Madani, K. (2014). Phytochemical screening of antioxidant and antibacterial activities of methanolic extracts of some Lamiaceae. Industrial Crops and Products, 61, 41-48. http://dx.doi.org/10.1016/j.indcrop.2014.06.037.

Kim, D. O., \& Lee, C. Y. (2004). Comprehensive study on vitamin C equivalent antioxidant capacity (VCEAC) of various polyphenolics in scavenging a free radical and its structural relationship. Critical Reviews in Food Science and Nutrition, 44(4), 253-273. PMid:15462129. http://dx.doi.org/10.1080/10408690490464960.

López, R., Ita, A., \& Vaca, M. (2009). Drying of prickly pear cactus cladodes (Opuntia ficus indica) in a forced convection tunnel. Energy Conversion and Management, 50(9), 2119-2126. http://dx.doi. org/10.1016/j.enconman.2009.04.014.

Lopez-Garcia, J., Fuentes-Rodriguez, J., \& Rodriguez, R. (2001). Production and use of Opuntia as forage in northern Mexico. In C. MongragonJacobo \& S. Perez-Gonzalez (Eds.), Cactus (Opuntia spp.) as forage (pp. 29-36). Rome: FAO Plant Production and Protection Paper.

Lou, Z., Wang, H., Rao, S., Sun, J., Ma, C., \& Li, J. (2012). P-Coumaric acid kills bacteria through dual damage mechanisms. Food Control, 25(2), 550-554. http://dx.doi.org/10.1016/j.foodcont.2011.11.022.

Pompeu, D. G., Mattioli, M. A., Ribeiro, R. I. M. A., Gonçalves, D. B., Magalhães, J. T., Marangoni, S., Silva, J. A., \& Granjeiro, P. A. (2015). Purification, partial characterization and antimicrobial activity of Lectin from Chenopodium Quinoa seeds. Food Science and Technology, 35(4), 696-703. http://dx.doi.org/10.1590/1678-457X.6823.

Prieto, P., Pineda, M., \& Aguilar, M. (1999). Spectrophotometric quantitation of antioxidant capacity through theformation of a Phosphomolybdenum Complex: specific application to the determination of vitamin E. Analytical Biochemistry, 269(2), 337341. PMid:10222007. http://dx.doi.org/10.1006/abio.1999.4019.

Ranalli, A., \& Angerosa, F. (1996). Integral centrifuges for olive oil extraction. The qualitative characteristics of products. Journal of the American Oil Chemists' Society, 73(4), 417-422. http://dx.doi. org/10.1007/BF02523912.

Ribeiro, E. M. O., Silva, H. N., Lima, J. L., Fo., Brito, J. Z., \& Silva, M. P. C. (2010). Study of carbohydrates present in the cladodes of Opuntia ficus-indica (fodder palm), according to age and season. Food Science 
and Technology, 30(4), 933-939. http://dx.doi.org/10.1590/S010120612010000400015.

Sáenz, H.C. (1997). Cladodes: a source of dietary fiber. Journal of the Professional Association for Cactus Development, 2, 117-123.

Shanmughapriya, S. A., Manilal, A., Sujith, S., Selvin, J., Kiran, G. S., \& Natarajaseenivasan, K. (2008). Antimicrobial activity of seaweeds extracts against multi-resistant pathogens. Annals of Microbiology, 58(3), 535-541. http://dx.doi.org/10.1007/BF03175554.

Shi, J., Yu, J., Pohorly, J., Young, C., Bryan, M., \& Wu, Y. (2006). Optimization of the extraction of polyphenols from grapes seed meal by aqueous ethanol solution. Food Agriculture and Environement, 1, 42-47.

Sousa, E. C., Uchôa-Thomaz, A. M. A., Carioca, J. O. B., Morais, S. M. D., Lima, A. D., Martins, C. G., Alexandrino, C. D., Ferreira, P. A. T., Rodrigues, A. L. M., Rodrigues, S. P., Silva, J. D. N., \& Rodrigues, L. L. (2014). Chemical composition and bioactive compounds of grape pomace (Vitis vinifera L.), Benitaka variety, grown in the semiarid region of Northeast Brazil. Food Science and Technology, 34(1), 135-142. http://dx.doi.org/10.1590/S0101-20612014000100020.
Teke, G. N., Kuiate, J. R., Kueté, V., Teponno, R. B., Tapondjou, L. A., Tane, P., Giacinti, G., \& Vilarem, G. (2011). Bio-guided isolation of potential antimicrobial and antioxidant agents from the stem bark of Trilepisium madagascariense. South African Journal of Botany, 77(2), 319-327. http://dx.doi.org/10.1016/j.sajb.2010.09.011.

Valente, L. M. M., Paixão, D., Nascimento, A. C., Santos, P. F. P., Scheinvar, L. A., Moura, M. R. L., Tinoco, L. W., Gomes, L. N. F., \& Silva, J. F. M. (2010). Antiradical activity, nutritional potential and flavonoids of the cladodes of Opuntia monacantha (Cactaceae). Food Chemistry, 123(4), 1127-1131. http://dx.doi.org/10.1016/j. foodchem.2010.05.074.

Wang, S. Y. (2003). Antioxidant capacity of berry crops, culinary herbs and medicinal herbs. Acta Horticulturae, 620(620), 461-473. http:// dx.doi.org/10.17660/ActaHortic.2003.620.56.

Zou, Y., Ma, K., \& Tian, M. (2015). Chemical composition and nutritive value of hot pepper seed (Capsicum annuum) grown in Northeast Region of China. Food Science and Technology, 35(4), 659-663. http://dx.doi.org/10.1590/1678-457X.6803. 